\title{
Bargaining power and information in SME lending
}

\author{
Jens Grunert • Lars Norden
}

Accepted: 10 December 2010/Published online: 19 January 2011

(C) The Author(s) 2011. This article is published with open access at Springerlink.com

\begin{abstract}
Small- and medium-sized enterprises (SMEs) are informationally opaque and bank dependent. In SME lending, banks largely rely on soft information, because the scale and scope of hard information are limited. We analyze whether and how hard and soft information affects the borrower's bargaining power vis-à-vis its bank. We use the fact that, for a given credit rating, certain borrowers obtain better loan terms than others to define measures of relative bargaining power. Using SME loan data from the USA and Germany, we find that more favorable soft information (management skills and character) increases borrower bargaining power. We also show that more favorable soft than hard information improves borrower bargaining power. The results are not driven by manipulation or statistical limitations of the credit ratings. Our study suggests that soft information represents an important and direct determinant of borrower bargaining power, affecting the outcomes of the loan contracting process.
\end{abstract}

Keywords SME lending - Bargaining power . Hard and soft information - Credit ratings . Loan terms

J. Grunert

University of Tübingen, Tübingen, Germany

L. Norden $(\bowtie)$

Rotterdam School of Management, Erasmus University, Rotterdam, The Netherlands

e-mail: lnorden@rsm.nl
JEL Classifications $\quad$ G21 $\cdot$ L11 $\cdot$ M13

\section{Introduction}

Small- and medium-sized enterprises (SMEs) have been characterized as relatively opaque and bank dependent (e.g., Petersen and Rajan 1994). Banks that lend to SMEs largely rely on soft information because the scale and scope of hard information are often limited. Consequently, the bank relationships of SMEs are particularly suited for an examination of the link between information on borrower quality and borrower bargaining power. Its main determinants are borrower characteristics (demand side), bank characteristics (supply side), bank-borrower relationship characteristics (previous interaction), and marketwide factors (competition, business cycle).

In this paper we analyze whether and how hard and soft information affects the borrower's bargaining power vis-à-vis its bank. While ideally we would like to analyze the bargaining effects by comparing the ex ante preferences of borrowers and banks on loan terms with actual contractual outcomes, we are unable to do so due to a lack of reliable data. Our approach to examine borrower bargaining power is by starting at the end of the loan contracting process and exploiting the cross-sectional variation of loan terms for borrowers with the same risk of default. If certain borrowers exhibit more favorable loan terms than others in the same credit rating category (controlling 
for borrower, bank, other loan terms, and macroeconomic effects), bargaining power might be one plausible explanation. Based on this reasoning, we define three measures of borrower-specific bargaining power that can be characterized as ex post, relative, and risk-adjusted. Our preferred measure is based on the loan contract term that is usually fixed last, the loan spread, and indicates a relatively high bargaining power for an individual borrower if the contracted loan spread lies below the median loan spread of same-rated borrowers. Such a favorable outcome of the bilateral bargaining might represent a net benefit for the borrower and a net cost for the bank. We also define further measures based on collateral and on a combination of loan spread and collateral.

Thus far, there is no evidence of whether bargaining power is affected by hard information, soft information or both. This question is highly relevant since the literature on SME finance and banking has emphasized the importance of soft information production (e.g., Boot 2000; Berger and Udell 2002; Petersen 2004). The issue also has important implications for firms borrowing from banks and for risk management, including incentive problems inside banks (e.g., Udell 1989; Stein 2002; Scott 2004; Liberti and Mian 2009; Hertzberg et al. 2010). Hard information typically refers to the borrower's financial statements and payment information, while soft information refers to the borrower's management skills, the product-market position, and his strategy. Hard information can be relatively easily gathered, stored, evaluated, and transmitted to third parties, while soft information is difficult to handle. Moreover, the notion of soft information is not well defined in the literature. In this paper, nonfinancial information, in particular the assessment of management skills, is considered as soft information (e.g., Petersen 2004; Grunert et al. 2005).

The empirical analysis of two micro data sets on loans to SMEs from the USA (2003 Survey of Small Business Finances; Board of Governors 2003) and Germany (detailed credit file data from six banks) yields the following results. First, we find that soft information is significantly positively related to borrower bargaining power. Second, a more favorable assessment of soft information compared with hard information is associated with higher borrower bargaining power. Third, borrower bargaining power exhibits persistence over time, which can be explained by the relatively high intertemporal stability of soft information. Fourth, we fail to find evidence that these results are driven by credit ratings manipulation or statistical limitations of the credit rating systems. Finally, various tests of robustness confirm the previous findings in both samples.

Our study contributes to the SME finance and banking literature in several ways. This is the first empirical study that explicitly links bargaining effects and information production in SME finance, providing new evidence for the role of hard and soft information in bank-borrower relationships. We show that there are second-order effects from soft information, especially from management skills and character. This type of soft information matters for both the credit rating level as well as the variation of loan terms within the credit rating categories as the manager directly influences the bargaining process with the bank. This channel is exclusively based on manager characteristics but not on hard information on the firm. Moreover, the robustness of the results in both the USA and Germany samples indicates that the link between bargaining power and soft information is not mitigated by institutional differences between countries. Finally, from a methodological perspective, we contribute by proposing robust measures of borrower bargaining power.

The remainder of this paper is organized as follows. Section 2 reviews the related literature and establishes our main hypothesis. Section 3 describes the data and provides a definition of the bargaining power measures. Section 4 reports the main results as well as further empirical checks. Section 5 summarizes the findings from numerous tests of robustness. Section 6 concludes.

\section{Related literature and hypothesis}

This study deals with a topic that is at the intersection of three areas of the SME finance and banking literature: determinants of lending terms, the role of hard and soft information in banking, and bargaining power in lending relationships.

First, we contribute to the empirical research on the determinants of lending terms, in particular on loan rates and collateral in SME lending (e.g., Petersen and Rajan 1994; Berger and Udell 1995; Blackwell and Winters 1997; Elsas and Krahnen 1998; Machauer 
and Weber 1998; Berger et al. 2005; Agarwal and Hauswald 2007; Cerqueiro et al. 2007; Heyman et al. 2008). Cerqueiro et al. (2007) interpret deviations of actual loan rates from predictions of a comprehensive loan pricing model as evidence for "rules and discretion" in bank behavior. It turns out that "discretion" is more important in the case of small and unsecured loans, small, risky, and opaque firms with relatively old owners, in weak bank-borrower relationships, and when bank competition is low. The key difference from our study is that we investigate how soft information affects the likelihood of having above (=high bargaining power) or below average (=low or no bargaining power) loan terms within a rating grade, independent of the strength of the variation, whereas Cerqueiro et al. (2007) distinguish between situations of high (=discretion) and low variation (=rules) in loan rates. In other words, they focus on the overall unexplained variation of lending terms, whereas this study looks inside a rating grade and ranks borrowers according to their loan terms. Furthermore, in contrast to most of the literature, we analyze how bargaining power is affected by the evaluation of soft and hard information and not by the effects arising from the amount of information available to the bank (informational asymmetries).

Second, we extend the literature that analyzes the type of information in banking, especially the importance of soft information (e.g., Burghof 2000; Berger and Udell 2002; Petersen 2004; Grunert et al. 2005; Agarwal and Hauswald 2007; Liberti and Mian 2009; Norden and Weber 2010). For example, Grunert et al. (2005) provide evidence that soft information represents an important factor in assessing the default risk of borrowers in SME finance. They find that a combination of financial (hard information: financial statement and payment information) and nonfinancial factors (soft information: management skills, the firm's product-market position and strategy) significantly improves the prediction accuracy of the internal credit rating systems of banks. While their results represent evidence for first-order effects from soft information, our study extends the literature by uncovering both the first-order effects as well as the second-order effects (i.e., soft information relates to the within-rating variation of loan terms).

Third, there are few studies that explicitly focus on bargaining power effects in bank-borrower relationships (e.g., Rudolph 2006; Uchida 2006; Wu and Wu
2007; Kirschenmann and Norden 2008). Uchida (2006) investigates the empirical determinants of bargaining power in bank-borrower relationships in Japan, measured by the transaction costs a contracting partner has to bear. On the one hand, stronger bank competition and better borrower performance raises the bargaining power of borrowers. On the other hand, the influence of asymmetric information is rather weak. More specifically, greater availability of hard information tends to decrease borrower bargaining power, but neither the bank's private information nor auditing financial statements play a significant role. Moreover, the study fails to find an impact of soft information on bargaining power, which is in contrast to our results on the link between borrower bargaining power and soft information. Furthermore, combining insights from finance and marketing, $\mathrm{Wu}$ and $\mathrm{Wu}$ (2007) analyze the intertemporal profitability of bank-customer relationships based on loan data from a leading bank in Taiwan. They document that the pattern of intertemporal changes of the price premium depends on borrower bargaining power. One difference from our study is that the proxy for borrower bargaining power used in the study by $\mathrm{Wu}$ and $\mathrm{Wu}$ (2007) is based on a borrower's revenue brought to the bank. Moreover, bargaining power is considered as an independent variable, while we use indicators for bargaining power as a dependent variable. Most importantly, the study relates intertemporal loan pricing to asymmetric information and bargaining power but not the type of information available to the bank. Finally, Santos and Winton (2009) analyze bank characteristics and bargaining power for a sample of large US borrowers from 1987 to 2007. They detect a negative relationship between the bank's capital level and the contracted loan spread.

Based on the literature summarized above, we propose the following main hypothesis: Borrower bargaining power depends more on soft information than on hard information. This hypothesis is motivated by the fact that the bank first assigns a credit rating to a borrower and then negotiates the loan terms. Moreover, hard information from financial statements or payment information fluctuates strongly over time and is largely driven by macroeconomic conditions. Favorable hard information does not necessarily materialize into strong relative bargaining power because the majority of borrowers exhibit good (bad) financial ratios in good (bad) times, 
especially firms from the same industry. In contrast, soft information such as management skills, productmarket characteristics, and firm strategy is more stable over time. Therefore, the evaluation of soft information may represent an important determinant of borrower bargaining power. In addition, it is conceivable that the firms that obtain a relatively favorable assessment of their soft information are better at negotiating because their managers are more experienced and better educated. Furthermore, if the assessment of soft information is better than that of hard information, relative borrower bargaining power should be higher than in the opposite case. In this context, we assume that the borrower has full knowledge about the relevant soft information and employs this knowledge during the loan contracting process with the bank.

\section{Data and definitions}

\subsection{Data}

We use data from the largest and third-largest banking systems in the world (USA and Germany) to analyze how the type of information available to the bank (hard, soft) relates to borrower bargaining power. This comparative analysis has several advantages. First, the USA and Germany differ in several institutional dimensions (market-based versus bankbased financial system, lending infrastructure such as legal and judicial system, creditor rights, bankruptcy laws, etc.; see Berger and Udell 2006). Differential findings might result from the cross-country heterogeneity, while similar findings would be evidence for a robust economic relationship (out-of-sample validation). Second, we believe that our results are characteristic for SME finance because they are based on data from countries with a very high share of SMEs. ${ }^{1}$ Hence, our analysis may have implications for SME finance in other developed countries (e.g., for a recent international survey see Beck et al. 2008). Third, the data come from different years and

\footnotetext{
$\overline{1}$ For example, $92 \%$ of all firms in Germany have fewer than ten employees (Federal Statistical Office 2009), and 95\% of all firms in Organisation for Economic Co-operation and Development (OECD) countries are SMEs.
}

many banks. Fourth, although there is considerable heterogeneity between the countries, the borrowing firms in both samples are relatively similar with respect to size, default risk (total assets, sales, and credit ratings), and lending terms (loan spreads, collateral).

The German data come from a unique data set including detailed credit file information from 1,062 loans (240 borrowers), granted by six large German banks during the period 1992-1996 (e.g., Elsas and Krahnen 1998; Machauer and Weber 1998; Grunert et al. 2005; Brunner and Krahnen 2008). The banks cover all three pillars in the German banking sector (four private commercial banks, one state-owned bank, and one cooperative central bank), and credit files were drawn randomly from each of the banks every year. ${ }^{2}$ The panel structure allows analysis of the cross-sectional and time-series variation in bargaining power and information available to the banks. The latter consists of hard information (FINRAT), soft information (MGRAT), and an overall bank internal credit rating. Hard information refers to financial statement information, while soft information refers to the firm's management skills (competence, education, leadership, and credibility), product-market position, and strategy. In the remainder, we consider management skills as the most relevant soft information, since we found in a preliminary analysis that the firm's product-market position and strategy do not significantly influence borrower bargaining power. ${ }^{3}$

The US data are from the Survey of Small Business Finance 2003 and include loans to 1,761 small firms (e.g., Board of Governors 2003; Mach and Wolken 2006; Cerqueiro et al. 2007; Park 2008). The analysis of bargaining power and information is based on one loan from each firm (the "most recent loan"). Hard information is measured by the Dun \& Bradstreet credit score (CREDIT_SCORE) as included in the

\footnotetext{
${ }^{2}$ Forty credit files were collected from six banks and 5 years (leading to a maximum number of 1,200 observations from 240 borrowers, of which 1,062 loans are complete and ready for the analysis). The number of 40 borrowers from each bank decomposes into 25 borrowers that were randomly drawn from the overall borrower population and 15 from the subsample of firms in financial distress. This sampling technique leads to overrepresentation of distressed firms in the entire sample. We address this issue in Sect. 5 and show that it does not affect our main results.

${ }^{3}$ We briefly summarize findings from this analysis in Sect. 5 .
} 
SSBF 2003. Proxies for soft information are the education of the owner $(E D U)$, his business experience/expertise (EXPER), and his age (AGE). All results remain unchanged if we use the weighted averages of these variables for all owners (as included in the SSBF 2003). The soft information variables for the US sample are similar to the inputs of MGRAT in the German sample and represent an integral part of the "C's of credit" 4 in the US banking industry (e.g., National Association of Credit Management 1965). Soft information is crucial for the assessment of the categories "character" and "capacity" (management ability). Bankers have pointed out that "there is no substitute for character-it is a vital factor" (Collins 1966). Furthermore, we consider the D\&B credit score as hard information, since it is based on financial statements and payment information and does not include the variables $E D U, E X P E R$, and $A G E$ (e.g., Kallberg and Udell 2003).

Table 1 reports summary statistics for both samples (panel A: German sample; panel B: US sample) for the type of information (hard, soft), various borrower characteristics, bank relationship characteristics, and loans terms (spread, collateral); bank competition is only available for the US sample.

The mean rating for financials ratios (hard information, FINRAT) is 3.66 in the German sample and 3.03 (CREDIT_SCORE) in the US sample. Moreover, in the German sample the assessment of soft information (MGRAT) exhibits a mean of 2.69, which is more favorable than the evaluation of hard information. The median log sales for the German firms amount to 11.59 , and to 14.65 for the US firms. The median $\log$ of total assets is higher for US firms (13.67) compared with the German sample (11.13). Turning to bank relationship characteristics, we observe that the median of the log number of bank relationships (log duration) is $1.6(5.3)$ in the German sample and 1.1 (4.3) in the US sample. Median loan spreads are 3.63 percentage pts in the German sample

\footnotetext{
$\overline{4}$ The "C's of credit" represent a long-established practice in the US banking industry to assess the creditworthiness of a borrower by examining the categories (1) character (integrity, honesty), (2) capacity (management ability), (3) capital, (4) collateral (which cannot substitute a weakness in character), and (5) conditions (business cycle, industry effects) (e.g., Collins 1966). Character and capacity are considered as the most important categories.
}

and 3.23 percentage pts in the US sample. The percentage of secured loans is $74 \%$ in the German sample (number not shown in Table 1; instead we report the ratio of collateral relative to the loan amount) and $55 \%$ in the US sample. The distribution of the credit scores for US firms is slightly more shifted to the better (left) end than the bank internal credit ratings for German firms. The mode of both distributions is rating grade 3 , the standard deviations are comparable (1.21 for Germany, 1.45 for the USA), and the overall shape of the distributions does not differ significantly.

Essentially, both samples are relatively similar and exhibit typical characteristics of SME lending in both countries.

\subsection{Defining borrower bargaining power}

Dealing with borrower bargaining power in empirical research is inherently challenging because it is a classical example for a latent variable. The ideal solution would be to compare the ex ante preferences of both contracting parties (bank, borrower) with the actual outcome of the loan negotiation process. Borrower bargaining power would be present if the contracted loan terms are closer to the borrower's ex ante preferences than to the bank's initial offer. Unfortunately, there are no reliable data on ex ante preferences about lending terms available for research. Therefore, we consider other reliable measures of borrower bargaining power. Specifically, we construct measures that:

1. Are based on observable, contracted loan terms (spread, collateral, a combination of both), i.e., the measures can be seen as ex post indicators of bargaining power,

2. Measure relative effects (not absolute effects), i.e., is bargaining power for borrower $i$ higher or lower than for borrower $j$, and

3. Are adjusted for observable determinants of default risk, i.e., we do not address the relation between absolute borrower bargaining power and overall default risk.

We define three nonparametric ex post measures of relative borrower bargaining power that are based on the cross-sectional variation of loan terms per credit rating category (loan spreads, collateral, or both). First, POWER 1 , our preferred measure, equals 1 if the 
Table 1 Summary statistics

\begin{tabular}{|c|c|c|c|c|c|}
\hline Category & Variable & Definition & Median & Mean & $N$ \\
\hline \multicolumn{6}{|c|}{ Panel A: German sample } \\
\hline \multicolumn{6}{|c|}{ Type of information } \\
\hline Hard & FINRAT & $\begin{array}{l}\text { Rating for hard information (financial statements), } \\
\text { scale of } 1 \text { (best) to } 6 \text { (worst) }\end{array}$ & 4 & 3.66 & 820 \\
\hline Soft & $M G R A T$ & $\begin{array}{l}\text { Rating for soft information (management skills), } \\
\text { scale of } 1 \text { (best) to } 6 \text { (worst) }\end{array}$ & 2 & 2.69 & 742 \\
\hline \multicolumn{6}{|c|}{ Borrower characteristics } \\
\hline & SALES & Log of total sales (DEM) & 11.59 & 11.55 & 913 \\
\hline & $T A$ & Log of total assets (DEM) & 11.13 & 11.17 & 915 \\
\hline \multicolumn{6}{|c|}{ Bank relationship characteristics } \\
\hline & DURATION & Log of the length of the bank relationship (months) & 5.25 & 5.10 & 1,002 \\
\hline & NUMBANK & Log of the number of bank relationships & 1.61 & 1.54 & 917 \\
\hline & HOUSEBANK & Main bank (dummy) & 0 & 0.39 & 1,062 \\
\hline & CREDIT_LINE & Existence of a line of credit (dummy) & 1 & 0.85 & 1,062 \\
\hline \multicolumn{6}{|l|}{ Loan terms } \\
\hline & SPREAD & Spread on line of credit (percentage pts) & 3.63 & 3.64 & 761 \\
\hline & COLLAT & Collateral relative to credit exposure (\%) & 29.72 & 35.91 & 1,062 \\
\hline \multicolumn{6}{|c|}{ Panel B: US sample } \\
\hline \multicolumn{6}{|c|}{ Type of information } \\
\hline Hard & CREDIT_SCORE & $\begin{array}{l}\text { Credit score based on financials and payment } \\
\text { information, scale from } 1 \text { (best) to } 6 \text { (worst), } \\
\text { included in reverse order of D\&B code }\end{array}$ & 3 & 3.03 & 1,756 \\
\hline \multirow[t]{3}{*}{ Soft } & $E D U$ & $\begin{array}{l}\text { Education of main owner, scale } \\
\text { from } 1 \text { (highest) to } 7 \text { (lowest) }\end{array}$ & 2 & 3.25 & 1,708 \\
\hline & EXPER & Expertise of main owner (years) & 23 & 23.34 & 1,708 \\
\hline & $A G E$ & Age of main owner (years) & 53 & 53.50 & 1,708 \\
\hline \multicolumn{6}{|c|}{ Borrower characteristics } \\
\hline & SALES & Log of total sales (USD) & 14.65 & 14.45 & 1,752 \\
\hline & $T A$ & Log of total assets (USD) & 13.67 & 13.51 & 1,751 \\
\hline & FIRM_AGE & Age of firm (years) & 16 & 18.28 & 1,761 \\
\hline & $U R B A N$ & Firm comes from metropolitan area (dummy) & 1 & 0.77 & 1,761 \\
\hline & WHITE & Main owner is White (dummy) & 1 & 0.95 & 1,708 \\
\hline & FEMALE & Main owner is female (dummy) & 0 & 0.16 & 1,708 \\
\hline & MANAGE & Main owner is manager (dummy) & 1 & 0.83 & 1,708 \\
\hline & NUMBANK & Log of the number of bank relationships & 1.10 & 1.12 & 1,760 \\
\hline \multicolumn{6}{|c|}{ Bank relationship characteristics } \\
\hline & DURATION & Log of the length of the relationship (months) & 4.27 & 3.89 & 1,761 \\
\hline & DISTANCE & Log of the bank-borrower distance (miles) & 1.79 & 2.06 & 1,760 \\
\hline & CHECK & Existence of a checking account (dummy) & 1 & 0.99 & 1,761 \\
\hline & $S A V$ & Existence of a savings account (dummy) & 0 & 0.33 & 1,761 \\
\hline & CREDIT_LINE & Existence of a line of credit (dummy) & 1 & 0.78 & 1,761 \\
\hline \multicolumn{6}{|l|}{ Loan terms } \\
\hline & SPREAD & Spread on most recent loan (percentage pts) & 3.23 & 3.38 & 1,761 \\
\hline & COLLAT & Loan is secured (dummy) & 1 & 0.55 & 1,761 \\
\hline Competition & $H H I$ & $\begin{array}{l}\text { Hirschman-Herfindahl index, scale from } 1 \\
\quad \text { (low concentration) to } 3 \text { (high concentration) }\end{array}$ & 2 & 2.41 & 1,761 \\
\hline
\end{tabular}

The data come from 1,062 loans to German firms granted by six large banks during the period 1992-1996 and 1,761 loans to US firms as included in the SSBF 2003 
contracted loan spread of borrower $i$ is below the median loan spread for same-rated borrowers, and 0 otherwise. Loan spreads are calculated as the difference between all-in rating-specific loan rates minus same-currency and same-maturity risk-free rates. The main argument here is that same-rated borrowers are expected to pay the same loan spread when borrowing from the same bank in the same year (controlling for maturity, collateral, etc.). Given that there is substantial variation within rating grades, the presence of bargaining power is not unlikely. Second, POWER2 equals 1 if the ratio of collateral relative to the loan amount for borrower $i$ is below the median of this ratio for same-rated borrowers in the German sample (or unsecured in the US sample), and 0 otherwise. Third, we define the ordinal variable $P O W E R 3$ as the sum of POWER1 and POWER2, considering bargaining on loan spreads and collateral simultaneously.

The underlying reasoning for these measures is the following. If borrowers manage to obtain loan terms that are more favorable (either lower loan spreads or less collateral or both) than those of similar borrowers (same risk of default, controlling for other loan terms such as maturity and collateral), it is likely that their bargaining power is relatively high compared with similar borrowers. The fact that there are differences in the probability of default for borrowers from the same credit rating categories (i.e., the risk of default is not exactly the same, only similar) does not explain the variation in loan spreads. This is because banks' loan pricing models use discrete credit ratings as input factors and not continuous default probabilities. We do not claim that bargaining power (either the high power of the borrower or low power of the bank or any combination) is the exclusive driver of the outcome in loan contracting. However, it is reasonable to assume that the final outcome is positively correlated with the level of borrower bargaining power. Hence, the previously defined measures may serve as indicators of bargaining power. In addition, it is important to emphasize that POWER1, POWER2, and POWER3 are risk adjusted (i.e., the fraction of borrowers with high and low bargaining power is 50\%:50\% in each credit rating grade). This implies that the measure is unrelated to the overall (absolute) borrower default risk by definition. ${ }^{5}$

\footnotetext{
5 The dominant view in the literature implies that bargaining power is negatively correlated with the overall default risk of a
}

There are several reasons why the loan spread represents a useful indicator for borrower bargaining power. Most importantly, consistent with literature and industry practice, we argue that the loan spread is the contractual term that is fixed last and, therefore, most likely to be subject to bargaining (e.g., Standard and Poor's 2006; Kirschenmann and Norden 2008; Bharath et al. 2009). ${ }^{6}$ In addition, there are other important reasons why the spread might be related to bargaining: (1) there is room for upward and downward bargaining on the loan spread (unlike collateral, since supply is limited on the borrower side), (2) the spread is the basis for bank competition in credit markets, and (3) the contracted spread directly affects the borrower's financial statements and cash flows (unlike collateral). Thus, POWERI is our preferred measure.

Nonetheless, we also take into account potential bargaining about collateral (POWER2) and the interaction between loan pricing and collateral requirements (POWER3). It is important to consider the potential effects arising from potentially endogenous loan terms. In particular, the literature (theory and empirical work) is not conclusive about whether contracted loan spreads and collateral work in the same or opposite direction (e.g., Dennis et al. 2000; Brick and Palia 2007). Hence, positive bargaining effects based on loan spreads might be amplified or mitigated by bargaining on collateral. This effect will be captured by the measure POWER3.

Finally, we argue that the loan approval decision, which is based on the credit rating, along with the nonprice terms of bank loans (e.g., loan purpose, loan type, amount, and maturity) are less or not subject to bargaining. The main reason why loan approval (credit availability) is unlikely to be subject to

\footnotetext{
Footnote 5 continued borrower, i.e., riskier borrowers have less bargaining power (e.g., Uchida 2006). However, one might also argue that highrisk borrowers exhibit high bargaining power if they are on the verge of bankruptcy and the bank cannot afford to liquidate the borrower immediately. This situation leaves room for renegotiations, raising the bargaining power of these borrowers.

${ }^{6}$ Given this order in the loan contracting process, potential endogeneity problems associated with the definition of our proxy for borrower bargaining power are minimized. In addition, the spread is fixed after the bank has assigned a credit rating to the borrower (which excludes endogeneity at this level); i.e., there is a causal relationship going from the rating to the spread.
} 
bargaining is that this decision is based on noncompensatory objectives. The bank defines an acceptable range for the probability of default (based on credit rating and scoring systems) and approves all loan applications within this range. If a borrower is beyond the cutoff point, it is very rare for the bank to trade off the elevated level of default risk with tighter loan terms. Instead, banks typically prefer to reject these loans outright. An additional reason is that the large majority of firms that apply for bank loans get an approval (e.g., more than $90 \%$ in the raw data set from the USA used in this study). Eventually, nonprice terms in loan contracting are usually predefined by the borrower's investment opportunities, and therefore less subject to bargaining than the loan spread.

Concerning our bargaining power measures, we find that the Spearman rank correlation between POWER1 and POWER2 in the German sample is significantly positive $(0.10, P<0.01)$ but significantly negative in the US sample $(-0.13, P<0.01)$. Therefore, we consider POWERI as the most robust proxy measure of borrower bargaining power.

\section{Empirical results}

\subsection{Univariate results}

We calculate rank correlations to gain insight on the influence of hard and soft information on borrower bargaining power. In the German sample, we use FINRAT as a proxy for hard information and MGRAT as a proxy for soft information, both measured on a scale from 1 (best) to 6 (worst). In the US sample, we use CREDIT_SCORE as a proxy for hard information (higher numbers indicate higher default risk) and $E D U, E X P E R$, and $A G E$ as proxies for soft information (EDU: smaller values indicate more favorable information). Table 2 reports the pairwise Spearman rank correlation coefficients between the information variables of firm size (based on log total sales) and the bargaining power measures POWER1, POWER2, and POWER3.

Panel A of Table 2 indicates the correlations for the German sample. Five out of six numbers are negative, indicating that a worse evaluation is associated with lower bargaining power. Most importantly, the correlation between borrower bargaining
Table 2 Rank correlation between the type of information, borrower size, and bargaining power

\begin{tabular}{lccc}
\hline Information & \multicolumn{2}{c}{ Measure of borrower bargaining power } \\
\cline { 2 - 4 } & POWER1 & POWER2 & POWER3 \\
\hline Panel A: German sample & & \\
Hard & & & \\
FINRAT & $-0.09^{* *}$ & -0.01 & $-0.07^{*}$ \\
Soft & & & \\
MGRAT & $-0.19^{* * *}$ & $-0.16^{* * *}$ & $-0.19^{* * *}$ \\
Size & & & \\
LARGE & $0.13^{* * *}$ & $0.13^{* * *}$ & $0.18^{* * *}$ \\
Panel B: US sample & & & \\
Hard & & & \\
CREDIT_SCORE & -0.00 & $-0.04^{* * *}$ & -0.03 \\
Soft & & & \\
EDU & $-0.05^{* *}$ & -0.02 & $-0.06^{* *}$ \\
EXPER & $0.08^{* * *}$ & $-0.07^{* * *}$ & 0.01 \\
AGE & $0.17^{* * *}$ & -0.03 & 0.03 \\
Size & & & -0.01 \\
LARGE & $0.17^{* * *}$ & $-0.19^{* * * *}$ & -0.03 \\
\hline
\end{tabular}

This table shows the Spearman rank correlation coefficients between the evaluation of hard (FINRAT; CREDIT_SCORE) and soft information (MGRAT; EDU, EXPER, and $\bar{A} G E)$ and the measures of borrower bargaining power ( $P O W E R 1$ equals 1 if the loan spread is below the median loan spread for samerated borrowers, and 0 otherwise; POWER2 equals 1 if the collateral relative to the loan amount is below the median ratio for same-rated borrowers, and 0 otherwise; POWER3 is the sum of POWER1 and POWER2). LARGE equals 1 if total $S A L E S$ exceeds the median of SALES, and 0 otherwise. The data come from 1,062 loans to German firms granted by six large banks during the period 1992-1996 and 1,761 loans to US firms as included in the SSBF 2003. ***, **, * denote correlation coefficients that are statistically significant at the $0.01,0.05$, and 0.10 levels

power and soft information ranges from -0.16 to -0.19 . Interestingly, these coefficients are all significantly different from 0 and clearly stronger than the link with hard information (which is only significant in the case of POWERI). In addition, we find that larger SMEs have more bargaining power. Panel B shows very similar findings for the USA. All correlations between soft information (EDU, EXPER, and $A G E)$ and POWERI are significantly negative, while hard information is not significant at all. In contrast to the German sample, hard information is significantly related to POWER2 for the US sample. In addition, the correlation between firm size and bargaining power is significantly positive for 
POWER1 and negative for POWER2 in the US sample.

The main results from this univariate analysis are consistent in both samples and confirm our hypothesis that soft information significantly affects borrower bargaining power, in particular for POWERI. There is also clear evidence that the assessment of soft information is a more important determinant for bargaining power than the assessment of hard information.

\subsection{Multivariate results}

We now analyze how the type of information affects borrower bargaining power by means of multivariate cross-sectional probit and ordered probit regression models for the German and US samples. The main goal is to examine which type of information matters more. For this purpose, we estimate the likelihood of high borrower bargaining power $(P O W E R 1=1$, $P O W E R 3=1)$. Explanatory variables for the German sample are the assessment of hard information (FINRAT), soft information (MGRAT), and control variables (borrower and relationship characteristics as proxies for borrower transparency and asymmetric information in the bank relationship as well as bank and year fixed effects). ${ }^{7}$ For the US sample, we use the credit score (CREDIT_SCORE, on a reverse scale, i.e., higher numbers correspond to higher default risk) as a proxy for hard information and EDU and EXPER as proxies for soft information (nonfinancial factors of borrower quality). ${ }^{8}$ In addition, we also include control variables (borrower and relationship characteristics as well as the Hirschman-Herfindahl index to consider effects from bank competition). We estimate four models for each sample (two models including the information variables only and two full models

\footnotetext{
7 If we include dummy variables for the credit rating grades (German sample: FINRAT, MGRAT; US sample: CREDIT_SCORE) instead of taking the ordinal variables, we obtain identical results. Moreover, if we orthogonalize MGRAT and FINRAT (or vice versa) using a modified Gram-Schmidt procedure, we still obtain that the orthogonalized variable $M G R A T$ is significantly negatively related to borrower bargaining power and FINRAT is not.

${ }^{8}$ We do not include $A G E$ (age of the firm owner) as a further variable because it is strongly positively correlated with $E D U$ and EXPER. Nonetheless, the results shown in Table 3 remain largely robust even if we include AGE.
}

for POWERI and POWER3, respectively). In models III and IV, we use ordered probit regressions because the dependent variables have more than two categories. Table 3 reports the results.

The regression results are strikingly clear and consistent across both samples: soft information matters for borrower bargaining power. Panels A and $\mathrm{B}$ in Table 3 indicate that soft information (negative coefficient of MGRAT in the German sample and of EDU or EXPER in the US sample) is associated with higher borrower bargaining power, regardless of whether we use POWERI or POWER3 as the dependent variable. In particular, the level of education $(E D U)$ is an important determinant of borrower bargaining power in the US sample. In contrast, hard information is not related to borrower bargaining power at all. These results confirm the univariate analysis from the previous section, and they are not driven by the correlation between hard and soft information. We obtain highly similar results if we run the regressions separately, including either the proxy for hard or soft information. Furthermore, firm size (SALES) has a consistently positive impact on borrower bargaining power.

We conclude that soft information has a significant impact on borrower bargaining power. The result is robust to different definitions of bargaining power and across samples.

\subsection{Additional empirical checks}

We conduct some additional empirical checks to extend the previous analysis in two directions. Given the significantly positive impact of soft information on borrower bargaining power, we subsequently shed light on the influence of differences in the assessment of hard and soft information (e.g., soft information more favorable than hard information or vice versa) and the persistence of borrower bargaining power over time. Furthermore, we investigate two important alternative explanations and find that they can be ruled out.

To analyze the first issue, we define the variable HMS ("hard minus soft"), measuring the differential assessment of hard and soft information (both are measured on an ordinal scale with higher numbers indicating worse outcomes). A higher value of $H M S$ indicates a better evaluation of soft relative to hard information. HMS ranges from -5 to 5 in the German 
Table 3 Relative borrower bargaining power, hard and soft information

\begin{tabular}{|c|c|c|c|c|c|c|c|c|}
\hline \multirow[t]{3}{*}{ Dep. var.: } & \multirow{2}{*}{\multicolumn{2}{|c|}{$\frac{\text { Model I (probit) }}{\text { POWERI }}$}} & \multirow{2}{*}{\multicolumn{2}{|c|}{$\frac{\text { Model II (probit) }}{\text { POWERI }}$}} & \multirow{2}{*}{\multicolumn{2}{|c|}{$\frac{\text { Model III (ordered probit) }}{\text { POWER3 }}$}} & \multirow{2}{*}{\multicolumn{2}{|c|}{$\frac{\text { Model IV (ordered probit) }}{\text { POWER3 }}$}} \\
\hline & & & & & & & & \\
\hline & Coeff. & $P$ value & Coeff. & $P$ value & Coeff. & $P$ value & Coeff. & $P$ value \\
\hline \multicolumn{9}{|c|}{ Panel A: German sample } \\
\hline FINRAT & 0.0570 & 0.240 & 0.0943 & 0.122 & 0.0419 & 0.307 & 0.0626 & 0.201 \\
\hline$M G R A T$ & $-0.1943 * * *$ & 0.004 & $-0.2398 * * *$ & 0.004 & $-0.1629 * * *$ & 0.006 & $-0.1471 * *$ & 0.040 \\
\hline SALES & & & $0.3128 * * *$ & 0.002 & & & $0.2178 * * *$ & 0.008 \\
\hline HOUSEBANK & & & -0.1017 & 0.577 & & & -0.0892 & 0.575 \\
\hline NUMBANK & & & -0.1644 & 0.192 & & & 0.0489 & 0.741 \\
\hline DURATION & & & -0.1253 & 0.207 & & & -0.0982 & 0.329 \\
\hline Bank fixed effects & Yes & & Yes & & Yes & & Yes & \\
\hline Year fixed effects & Yes & & Yes & & Yes & & Yes & \\
\hline Obs. & 571 & & 424 & & 571 & & 424 & \\
\hline Pseudo- $R^{2}$ & 0.1920 & & 0.2555 & & 0.0785 & & 0.0970 & \\
\hline \multicolumn{9}{|l|}{ Panel B: US sample } \\
\hline CREDIT_SCORE & 0.0122 & 0.565 & 0.0128 & 0.556 & -0.0226 & 0.238 & -0.0286 & 0.139 \\
\hline$E D U$ & $-0.0426 * * *$ & 0.007 & $-0.0295 *$ & 0.069 & $-0.0342 * *$ & 0.016 & $-0.0387 * * *$ & 0.007 \\
\hline EXPER & $0.0088^{* * *}$ & 0.001 & $0.0072 * *$ & 0.014 & 0.0006 & 0.807 & 0.0022 & 0.406 \\
\hline SALES & & & $0.0953 * * *$ & 0.000 & & & -0.0106 & 0.491 \\
\hline NUMBANK & & & -0.0185 & 0.821 & & & -0.0708 & 0.328 \\
\hline WHITE & & & -0.0946 & 0.500 & & & -0.0180 & 0.870 \\
\hline FEMALE & & & -0.0781 & 0.373 & & & -0.1258 & 0.103 \\
\hline DURATION & & & $-0.0684 * * *$ & 0.001 & & & -0.0029 & 0.870 \\
\hline DISTANCE & & & -0.0053 & 0.795 & & & -0.0245 & 0.147 \\
\hline$H H I \_2$ & & & 0.0634 & 0.630 & & & 0.0372 & 0.761 \\
\hline HHI_3 & & & 0.0039 & 0.977 & & & -0.0833 & 0.494 \\
\hline Obs. & 1,703 & & 1,695 & & 1,703 & & 1,695 & \\
\hline Pseudo- $R^{2}$ & 0.0073 & & 0.0252 & & 0.0023 & & 0.0062 & \\
\hline
\end{tabular}

The dependent variables POWERI $(0,1)$ or POWER3 $(0,1,2)$ measure the relative borrower bargaining power. Models I and II are probit models, models III and IV are ordered probit models. Explanatory variables in panel A are the financial rating (FINRAT), the nonfinancial rating $(M G R A T)$, the natural $\log$ of total SALES, a variable indicating whether the lender is the housebank (HOUSEBANK), a variable indicating the log of the number of bank relationships (NUMBANK), the log duration of the bank-firm relationship (in months), and bank and year fixed effects. The data come from 1,062 loans to German firms granted by six large banks during the period 1992-1996. Explanatory variables in panel B are the CREDIT_SCORE from D\&B, the education (EDU), business experience $(E X P E R)$, the $\log$ of total SALES, the log of the number of bank relationships (NUMBANK), and the race (WHITE) and gender (FEMALE) of the owner. DURATION is the log length of the bank relationship (in months), and DISTANCE is the log of the physical distance in miles between the borrower and his bank. HHI_2 and HHI_3 are indicator variables (with $H H I \_1$ as reference category) for local bank competition, based on the Hirschman-Herfindahl index. The data come from 1,761 loans to US firms as included in the SSBF 2003. All regressions consider the clustering of observations at the borrower level, and $P$-values are calculated from Huber-White robust standard errors. $* * *, * * *$ denote coefficients that are statistically significant at the $0.01,0.05$, and 0.10 levels

sample since the rating for hard (FINRAT) and soft (MGRAT) information are measured on a six-grade scale. For the US sample, we transform the credit score into a binary variable that equals 0 for scores from 1 to 3 and 1 for scores from 4 to 6 . In addition, the variable indicating the level of education is transformed to 0 if education belongs to the two highest categories (college degree or postgraduate degree), and 1 otherwise. Accordingly, HMS ranges from -1 to 1 in the US sample. Univariate tests indicate that a more favorable relative evaluation of soft information is associated with a higher borrower 
bargaining power; for example, the values of $H M S$ are $0.88(P O W E R 3=1), 0.97(P O W E R 3=2)$, and $1.25(P O W E R 3=3)$ in the German sample, indicating that better evaluation of soft information is associated with more bargaining power (the difference in HMS between POWER2 and POWER3 is statistically significant at the 0.05 level).

Table 4 reports the results of the multivariate analysis. Interestingly, the coefficient of $H M S$ is highly significant and positively associated with POWER1 in both the German and US samples. In addition, we observe a similar, slightly weaker result for the less preferred measure POWER3. Based on these multivariate results, we conclude that borrower bargaining power increases the more favorable the evaluation of soft relative to hard information.

We next examine the stability of borrower bargaining power over time. This is an interesting issue since it relates to the underlying economic forces leading to bargaining power. Based on the findings that soft information tends to be evaluated more favorably and less volatile over time than hard information (e.g., Grunert et al. 2005), we hypothesize that borrower bargaining power is relatively stable over time. In other words, "bargaining power today" can be expected to be positively correlated with "bargaining power tomorrow." We believe that this view is reasonable as long as the firm operates under regular conditions (same management, ${ }^{9}$ same products, same strategy, etc.). To test this hypothesis empirically, we recalculate the measure $P O W E R I$ based on rating- and year-specific median loan spreads (e.g., $P O W E R I=1$ if loan spread for borrower $i$ is below the median loan spread for same-rated firms in the same year). We then calculate lag 1 and 2 of the year-specific bargaining measure and test whether $\operatorname{POWERI}(t-1)$ and $P O W E R l(t-2)$ are significant predictors for POWERI $(t)$. For this purpose, the panel structure of the German data set is well suited whereas the crosssectional data from the USA does not allow us to conduct a similar test. Table 5 summarizes the estimation results. $^{10}$

\footnotetext{
$\overline{9}$ We do not have information on management turnover. Therefore, we cannot study bargaining power effects arising from management replacement, succession, layoffs, etc.

${ }^{10}$ Instead of cross-sectional time-series pooled ordinary least squares (OLS) estimations (with heteroscedasticity-adjusted standard errors and controlling for clustering on borrowers), we
}

The regression analyses reveal that the preferred measure of borrower bargaining power exhibits significant persistence over time. Specifically, the coefficient of POWERI $(t-1)$ is highly significant and positive, while lag 2 turns out to be insignificant. Hence, bargaining power exhibits considerable stability over time, consistent with the strong influence of soft information and the above-mentioned characteristics of the latter (better evaluation and lower intertemporal variability than hard information).

We now turn to potential alternative explanations of our previous results. First, one may argue that our findings are driven by credit ratings manipulation, in particular the assessment of soft information. If the borrower and the loan officer have aligned incentives (i.e., both intend to grant the loan anyway), the credit rating for soft information might exhibit a positive bias. This incentive structure is not unlikely if the borrower has relatively urgent liquidity needs and the loan officer's pay is based on volume, which has been the standard for many years and in many countries (Udell 1989). Moreover, a manipulation of soft information might be more difficult to detect (and/ or easier to implement) in comparison with a manipulation of hard information (e.g., Hertzberg et al. 2010).

We believe that this explanation can be ruled out for several reasons. First, banks rely on credit ratings and scores for various management purposes (e.g., loan approval, loan pricing, loan monitoring, loan loss provision, economic capital requirements, etc.) as well as, recently, for regulatory purposes (e.g., regulatory capital requirements, Basel II). Consequently, credit rating manipulation would do harm to their risk management and compliance with regulatory requirements. Second, a manipulation of the credit score by a US bank is highly unlikely since it comes from a third-party provider (Dun \& Bradstreet). In addition, the education, business experience, and age of the owner (EDU, EXPER, and $A G E$ ) variables represent raw data that can relatively easily be verified, and therefore, the evaluation is

Footnote 10 continued have also applied the random-effects panel estimator and obtain very similar findings. In particular, bargaining power turns out to be serially correlated at a lag of 1 year (but not over 2 years) within borrowers. 
Table 4 Bargaining power and differential assessment of hard and soft information

\begin{tabular}{|c|c|c|c|c|}
\hline \multirow[t]{3}{*}{ Dep. var.: } & \multicolumn{2}{|c|}{ Model I (probit) } & \multicolumn{2}{|c|}{ Model II (ordered probit) } \\
\hline & \multicolumn{2}{|l|}{ POWER1 } & \multicolumn{2}{|l|}{ POWER3 } \\
\hline & Coeff. & $P$-value & Coeff. & $P$-value \\
\hline \multicolumn{5}{|c|}{ Panel A: German sample } \\
\hline$H M S$ & $0.1269 * *$ & 0.033 & $0.0835^{*}$ & 0.082 \\
\hline SALES & $0.3308 * * *$ & 0.001 & $0.2341 * * *$ & 0.004 \\
\hline HOUSEBANK & -0.0989 & 0.592 & -0.0910 & 0.567 \\
\hline$N U M B A N K$ & -0.1676 & 0.181 & 0.0437 & 0.766 \\
\hline DURATION & -0.1161 & 0.248 & -0.0972 & 0.336 \\
\hline Bank fixed effects & Yes & & Yes & \\
\hline Year fixed effects & Yes & & Yes & \\
\hline Obs. & 424 & & 430 & \\
\hline Pseudo- $R^{2}$ & 0.2481 & & 0.1005 & \\
\hline \multicolumn{5}{|l|}{ Panel B: US sample } \\
\hline$H M S$ & $0.0955 * *$ & 0.041 & $0.0750 *$ & 0.069 \\
\hline SALES & $0.1057 * * *$ & 0.000 & -0.0010 & 0.947 \\
\hline$N U M B A N K$ & -0.0153 & 0.852 & -0.0684 & 0.345 \\
\hline WHITE & -0.1326 & 0.343 & -0.0280 & 0.789 \\
\hline FEMALE & -0.0449 & 0.602 & -0.1092 & 0.152 \\
\hline DURATION & $-0.0594 * * *$ & 0.003 & 0.0020 & 0.906 \\
\hline DISTANCE & -0.0059 & 0.769 & -0.0265 & 0.116 \\
\hline$H H I \_2$ & 0.0641 & 0.627 & 0.0392 & 0.747 \\
\hline HHI_3 & 0.0071 & 0.0957 & -0.00754 & 0.533 \\
\hline Obs. & 1,695 & & 1,695 & \\
\hline Pseudo- $R^{2}$ & 0.0231 & & 0.0041 & \\
\hline
\end{tabular}

The dependent variables POWER1 $(0,1)$ or POWER3 $(0,1,2)$ measure the relative borrower bargaining power. Model I is a probit model and model II is an ordered probit model. The key explanatory variable is HMS (hard minus soft) measuring the difference in the assessment of hard and soft information (both types of information are measured on an ordinal scale with higher numbers indicating worse outcomes). The higher the value of $H M S$, the better the evaluation of soft information. $H M S$ ranges from -5 to 5 in the German sample (six-grade scale for FINRAT and MGRAT), and from -1 to 1 in the US sample [the credit score is transformed into a binary variable which equals 0 for scores from 1 to 3 and equals 1 for scores from 4 to 6 ; the $E D U$ indicator is transformed to 0 if education is relatively high ( $E D U$ assumes the value 6 or 7) and 1 otherwise]. All regressions consider the clustering of observations at the borrower level, and $P$-values are calculated from Huber-White robust standard errors. ***, **, * denote coefficients that are statistically significant at the $0.01,0.05$, and 0.10 levels

completely unambiguous. For the German sample, a manipulation of soft information might improve the overall rating of a borrower, but this does not affect our measures of relative borrower bargaining power. These measures exhibit a "built-in bias" against this manipulation effect, because an upward-manipulated rating triggers a different benchmark for the loan spread (the median loan spread of the better rating grade) based on which we calculate the bargaining power measures. If the rating were improved by one grade, the resulting loan spread would be lower.
However, it is very likely that the new loan spread lies above the median spread of the better rating grade (i.e., our measure would indicate a relatively low bargaining power). Third, a ratings manipulation should result in a lower ability to predict future borrower defaults. One cannot reasonably expect that a bank would tolerate such behavior. To check this issue, we regress the default status of the firm on the ratings for hard and soft information. If the ratings for soft information are manipulated towards more favorable assessments, we expect only a weak or no 
Table 5 Persistence of borrower bargaining power

\begin{tabular}{|c|c|c|c|c|}
\hline \multirow[t]{3}{*}{ Dep. var.: } & \multicolumn{2}{|c|}{ Model I (probit) } & \multicolumn{2}{|c|}{ Model II (probit) } \\
\hline & \multicolumn{2}{|l|}{ POWERI ${ }_{t}$} & \multicolumn{2}{|l|}{ POWER $1_{t}$} \\
\hline & Coeff. & $P$-value & Coeff. & $P$-value \\
\hline POWER $1_{t-1}$ & 0.6241 *** & 0.000 & 0.7963 *** & 0.000 \\
\hline POWER $l_{t-2}$ & & & 0.2230 & 0.173 \\
\hline SALES & $0.2720 * * *$ & 0.001 & $0.2131 * *$ & 0.022 \\
\hline HOUSEBANK & 0.0205 & 0.886 & 0.1295 & 0.437 \\
\hline NUMBANK & 0.0351 & 0.748 & -0.0423 & 0.751 \\
\hline DURATION & $-0.1438^{*}$ & 0.070 & -0.0690 & 0.474 \\
\hline Bank fixed effects & Yes & & Yes & \\
\hline Year fixed effects & Yes & & Yes & \\
\hline Obs. & 550 & & 382 & \\
\hline Pseudo- $R^{2}$ & 0.1179 & & 0.1545 & \\
\hline
\end{tabular}

The dependent variable $P O W E R I_{t}(0,1)$ measures the relative borrower bargaining power on a year-by-year basis. Explanatory variables are lag 1 and lag 2 of the dependent variable as well as the natural log of total SALES, a variable indicating whether the lender is the housebank (HOUSEBANK), a variable indicating the log of the number of bank relationships (NUMBANK), the log duration of the bank-firm relationship (DURATION), and bank and year fixed effects. The data come from the German sample. All regressions consider the clustering of observations at the borrower level, and $P$-values are calculated from Huber-White robust standard errors. ***,**,* denote coefficients that are statistically significant at the $0.01,0.05$, and 0.10 levels

significant relation to future borrower defaults. ${ }^{11}$ Table 6 presents the results.

The findings from the probit model estimations show that credit rating manipulation cannot serve as an explanation. For the German sample (panel A of Table 6), the coefficients of the contemporaneous ratings for hard and soft information are all significantly positively related to future defaults events $[D E F(t+1)]$ at the 0.01 level. These results clearly show that the evaluation of hard information (FIN$R A T)$ and soft information (MGRAT) are strongly

\footnotetext{
11 This approach allows us to test whether ratings are substantially manipulated. Unfortunately, we cannot examine whether ratings are moderately manipulated, but the previous discussion as well as internal and external controls (e.g., internal asset quality review units, internal audits, external audits, bank supervisors) suggest that even a moderate manipulation is relatively unlikely. This reasoning is also the main motivation behind the so-called use test, a requirement for the recognition of bank internal rating systems to determine regulatory capital requirements (Basel Committee on Banking Supervision 2006).
}

related to the default risk of the borrowers and, therefore, are not likely to be manipulated. For the US sample (panel B of Table 6), we get similar results: both the credit score from $D \& B$ and our proxy for soft information $(E D U)$ are significantly positively related to the indicator of default risk $(D E F)$. Note that we do not claim any causal relationships in this context: the main purpose here is to examine the statistical link between the ratings and default risk. Furthermore, one could argue that the probability of default varies even within the same rating grade and that causes different spreads. However, in banking practice, loan pricing is based on the credit rating and not on the exact estimation of a continuous probability of default. Therefore, it is not unlikely that (same-rated) firms who get better loan terms are better at bargaining with the bank.

A further alternative explanation for our findings might be that loan spreads are better ex ante proxies for the risk of default than credit ratings. This argument is not unrealistic since there is substantial variation in loan spreads within a credit grade (which is also due to the collateral pledged by the borrower). It is possible that the bank uses additional information that goes beyond the constituents of the credit rating to set the loan rate (including the decision to grant secured versus unsecured loans). If this information is highly default sensitive, the contracted loan spread might be a better predictor of default than the credit ratings. This reasoning is completely unrelated to bargaining power and leads to the empirical hypothesis that borrowers with loan spreads below the median loan spread for same-rated borrowers exhibit a lower ex post default rate. We test this hypothesis for the German sample by regressing future defaults $D E F(t+1)$ on the year- and borrower-specific bargaining power measure $P O W E R l(t)$, including bank and year fixed effects. It turns out that the coefficient of POWERl( $t)$ is negative but not statistically significant $(P=0.373)$. The pseudo- $R^{2}$ is very low and mainly driven by the bank and year fixed effects; without the latter the pseudo- $R^{2}$ is almost zero. This outcome is also consistent with the fact that the credit ratings are highly related with future default events (Table 6). Finally, for the US sample, we do not find a significant difference in estimated probability of default (based on the delinquency status 60 days past due during the last 3 years). Consequently, we rule out this alternative explanation. 
Table 6 The relation between hard and soft information and default risk

\begin{tabular}{|c|c|c|c|c|c|c|}
\hline \multicolumn{7}{|c|}{ Panel A: German sample } \\
\hline \multirow[t]{3}{*}{ Dep. var.: } & \multicolumn{2}{|c|}{ Model I (probit) } & \multicolumn{2}{|c|}{ Model II (probit) } & \multicolumn{2}{|c|}{ Model III (probit) } \\
\hline & \multicolumn{2}{|l|}{$D E F_{t+1}$} & \multicolumn{2}{|c|}{$D E F_{t+1}$} & \multicolumn{2}{|l|}{$D E F_{t+1}$} \\
\hline & Coeff. & $P$-value & Coeff. & $P$-value & Coeff. & $P$-value \\
\hline FINRAT & $0.34 * * *$ & 0.000 & & & $0.33 * * *$ & 0.000 \\
\hline$M G R A T$ & & & $0.28 * * *$ & 0.000 & $0.18 * * *$ & 0.007 \\
\hline Bank fixed effects & Yes & & Yes & & Yes & \\
\hline Year fixed effects & Yes & & Yes & & Yes & \\
\hline Obs. & 572 & & 572 & & 572 & \\
\hline Pseudo- $R^{2}$ & 0.2310 & & 0.1721 & & 0.2558 & \\
\hline \multicolumn{7}{|l|}{ Panel B: US sample } \\
\hline \multirow[t]{3}{*}{ Dep. var.: } & \multicolumn{2}{|c|}{ Model I (probit) } & \multicolumn{2}{|c|}{ Model II (probit) } & \multicolumn{2}{|c|}{ Model III (probit) } \\
\hline & \multicolumn{2}{|l|}{$D E F$} & \multicolumn{2}{|l|}{$D E F$} & \multicolumn{2}{|l|}{$D E F$} \\
\hline & Coeff. & $P$-value & Coeff. & $P$-value & Coeff. & $P$-value \\
\hline CREDIT_SCORE & $0.32 * * *$ & 0.000 & & & $0.33 * * *$ & 0.000 \\
\hline$E D U$ & & & $0.14 * *$ & 0.041 & $0.13 *$ & 0.069 \\
\hline Obs. & 1,703 & & 1,703 & & 1,703 & \\
\hline Pseudo- $R^{2}$ & 0.1096 & & 0.0023 & & 0.1094 & \\
\hline
\end{tabular}

For the German sample, the dependent variable $D E F_{t+1}$ equals 1 if there is a jump to default in the following year, and 0 otherwise. Explanatory variables are the rating based on financial information (FINRAT) and the rating based on soft information $(M G R A T)$. For the US sample, the dependent variable $D E F$ equals 1 if the firm was at least once delinquent 60 days or more on one of its business obligations during the past 3 years. Explanatory variables are the credit score (CREDIT_SCORE) in reverse order (higher numbers indicate riskier borrowers) and binary variable for the level of education of the firm owner $(E D U)$. All regressions consider the clustering of observations at the borrower level, and $P$-values are calculated from Huber-White robust standard errors. $* * *, * *, *$ denote coefficients that are statistically significant at the $0.01,0.05$, and 0.10 levels

\section{Tests of robustness}

For the first test of robustness, ${ }^{12}$ we repeat the main analysis for performing loans only (rating grades 1-4). It turns out that the influence of our proxies for soft information (MGRAT in the German sample, EDU and EXPER in the US sample) on $P O W E R 1$ remains highly significant $(P<0.01)$ and the estimated coefficient almost doubles (from -0.24 as reported in Table 3, panel A, model II to -0.46 ; similarly for $P O W E R 3$ as a dependent variable). For nonperforming loans, neither hard nor soft information is significantly related to bargaining power. Hence, our key results become even stronger when considering performing loans only.

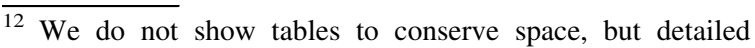
results are available from the authors on request.
}

Second, we test whether other soft information, such as information on the firm's product-market position and strategy (MSRAT), influences borrower bargaining power. This test is only possible for the German sample. For this purpose, we re-estimate the models shown in Tables 3 and 4 and find that the subrating for the firm's product-market position and strategy does not affect borrower bargaining power. We also regress POWERI (and POWER3) on FIN$R A T, M G R A T$, and MSRAT jointly and find that only $M G R A T$ is significantly related to borrower bargaining power. This finding is consistent with our view that there are second-order effects from management skills.

Third, we consider alternative definitions of the bargaining power measure. Specifically, we estimate a two-stage multivariate regression model to obtain the new binary measure POWER4, taking into 
account simultaneous effects coming from bargaining on loan spreads and collateral in a different way than POWER3. This allows us to address potential concerns about endogeneity in an elegant manner. At the first stage, we regress the observed loan spread on the bank internal ratings (CREDIT_SCORE, EDU, and EXPER) and the ratio of collateral relative to loan size (the indicator variable for secured loans) for the German sample (US sample) to obtain predicted loan spreads. POWER4 equals 1 if the actual loan spread is smaller than the predicted loan spread, and 0 otherwise. The rank correlation with POWERI is 0.48 , indicating that this measure is different but still positively related with our previous measures. We then re-estimate the main regression models (with and without control variables) for the German and US sample and get very similar results as in Table 3. In addition, we have also redefined POWERl and POWER 2 based on terciles to make a sharper distinction between borrowers with high, neutral, and low bargaining power. ${ }^{13}$ Again we find that soft information has significant influence.

Fourth, the analysis in the German sample refers to loan spreads from lines of credit only, whereas our findings for the US sample are based on different loan types. To make the samples comparable with respect to loan type, we select all lines of credit from the US sample $(1,110$ out of 1,761$)$, re-estimate the main regressions, and get very similar findings. In addition, if we distinguish between bargaining on new lines of credit and renewals, we cannot find any significant difference. In both cases, soft information (and not hard information) is significantly related to POWER1.

Fifth, in further analyses we investigated whether physical distance (e.g., DeYoung et al. 2008) or the mode of communication, in particular "personal" versus “impersonal” (e.g., Petersen and Rajan 2002; Berger et al. 2005), affects the statistical significance

\footnotetext{
13 We have also investigated whether the magnitude of borrower bargaining power (instead of binary indicators or ordinal measures) relates to soft information. For this purpose, we created a measure that is based on the difference between borrower's actual loan spread and median spread for samerated borrowers, and standardized this measure to the interval $(0,1)$. Then, we estimated Tobit regression models (because of the two-sided censoring) with the same explanatory variables as in Table 3. The analysis reveals that soft information is also significantly positively related to the magnitude of borrower bargaining power in both samples.
}

or economic magnitude of our findings. It is noteworthy that none of these variables change our finding that the assessment of soft information is significantly associated with borrower bargaining power.

Finally, we examine the impact of continuous measures of hard information instead of using ordinal ratings (FINRAT, CREDIT_SCORE). To analyze this issue, we include two standard measures for profitability and capital structure (ROA, LEVERAGE) as explanatory variables. These factors are key inputs for the financial rating of firms in the USA and Germany. For both samples, we find that more favorable soft information leads to higher borrower bargaining power, while ROA and LEVERAGE have no impact.

\section{Conclusions}

Bargaining and information are key elements of loan contracting. We analyze whether and how hard and soft information affects the borrower's bargaining power vis-à-vis its bank. In the absence of reliable data on ex ante preferences of banks and borrowers, we define measures of relative borrower bargaining power that exploit the variation of loan terms within credit rating categories.

Using SME loan data from the USA and Germany, we find support for the hypothesis that the assessment of soft information (management skills and character) is significantly positively related to borrower bargaining power. Moreover, a more favorable evaluation of soft relative to hard information is associated with higher borrower bargaining power. Most importantly, these two results provide evidence in favor of second-order effects from soft information. The latter not only affects the rating level but also influences the loan terms within the credit rating categories. We do not find second-order effects from hard information or soft information on the firm's product-market position and strategy (i.e., the effect is exclusively based on characteristics of the manager). One explanation for this result is that managers with more skill and experience are likely to use more differentiated communication and argumentation strategies when negotiating with their banks. Moreover, we show that borrower bargaining power persists over time, which is consistent with the relatively high stability of soft information. Finally, we rule out that the results are driven by ratings manipulation or the statistical 
limitations of the rating systems. A series of robustness tests confirm the previous findings.

Our study has several implications for banks and firms and offers interesting avenues for further research. First, both bargaining power and soft information relate to the strength of the bankborrower relationship. Hertzberg et al. (2010) show that loan officer turnover is an effective device used to maintain incentives inside the bank (i.e., to avoid collusion between loan officers and borrowers). Our study suggests that a more favorable assessment of soft information increases borrower bargaining power. Since the evaluation of soft information depends, among other factors, on the loan officer's experience with the borrower, it is reasonable that new loan officers tend to make an "average assessment" to trade off the risk assessment and lending volume. Consequently, loan officer rotation helps to avoid a systematic drift towards increasing borrower bargaining power over time, arising either from gradually increasing accuracy of the loan officer's assessment or from collusion. Second, a related implication is that loan officers might have to bear the negative consequences individually arising from high borrower bargaining power. If they are paid according to the contracted loan rate margins, lower spreads would reduce their variable compensation. Third, there are also implications for bank competition; for example, the number and structure of bank relationships as well as switching costs of borrowers might relate to the interaction between bargaining power and soft information in banking. Fourth, analyzing how our findings on bargaining power and soft information relate to the literature on information sharing is beyond the scope of this paper. Finally, our results are good news for SMEs in the sense that improving their management skills and character may lead to more favorable loan terms.

Open Access This article is distributed under the terms of the Creative Commons Attribution Noncommercial License which permits any noncommercial use, distribution, and reproduction in any medium, provided the original author(s) and source are credited.

\section{References}

Agarwal, S., \& Hauswald, R. (2007). The choice between arm's-length and relationship debt: Evidence from eLoans. Working Paper, March 2007.
Basel Committee on Banking Supervision (2006). Basel II: International convergence of capital measurement and capital standards: A Revised Framework.

Beck, T., Demirgüc-Kunt, A., Martinez Peria, M.S. (2008). Bank financing for SMEs around the world: Drivers, obstacles, business models, and lending practices. Policy Research Working Paper 4785, November 2008.

Berger, A., \& Udell, G. (1995). Relationship lending and lines of credit in small firm finance. Journal of Business, 68, 351-381.

Berger, A., \& Udell, G. (2002). Small business credit availability and relationship lending: The importance of bank organisational structure. Economic Journal, 112, F32-F53.

Berger, A., \& Udell, G. (2006). A more complete conceptual framework for SME finance. Journal of Banking \& Finance, 30, 2945-2966.

Berger, A., Miller, N., Petersen, M., Rajan, R., \& Stein, J. (2005). Does function follow organizational form? Evidence from the lending practices of large and small banks. Journal of Financial Economics, 76, 237-269.

Bharath, S., Dahiya, S., Saunders, A., Srinivasan, A. (2009). Lending relationships and loan contract terms. Forthcoming Review of Financial Studies.

Blackwell, D., \& Winters, D. (1997). Banking relationships and the effect of monitoring in loan pricing. Journal of Financial Research, 20, 275-289.

Board of Governors (2003). 2003 survey of small business finances. Federal Reserve System, Washington, DC.

Boot, A. (2000). Relationship banking: What do we know? Journal of Financial Intermediation, 9, 7-25.

Brick, I., \& Palia, D. (2007). Evidence of jointness in the terms of relationship lending. Journal of Financial Intermediation, 16, 452-476.

Brunner, A., \& Krahnen, J. (2008). Multiple lenders and corporate distress: Evidence on debt restructuring. Review of Economic Studies, 75, 415-442.

Burghof, H.-P. (2000). Credit and information in universal banking. Schmalenbach Business Review, 52, 282-309.

Cerqueiro, G., Degryse, H., Ongena, S. (2007). Rules versus discretion in loan rate setting. CentER Discussion Paper No. 2007-59, Tilburg University.

Collins, N. (1966). Credit analysis-concepts and objectives. In: Baughn, W.H., Walker, C.E. (Eds.), The banker's handbook (pp 279-289), Homewood: Dow Jones-Irwin.

Dennis, S., Nandy, D., \& Sharpe, I. (2000). The determinants of contract terms in bank revolving credit agreements. Journal of Financial and Quantitative Analysis, 35, 87-110.

DeYoung, R., Glennon, D., \& Nigro, P. (2008). Borrowerlender distance, credit scoring, and loan performance: Evidence from informational-opaque small business borrowers. Journal of Financial Intermediation, 17, 113-143.

Elsas, R., \& Krahnen, J. (1998). Is relationship special? Evidence from credit-file data in Germany. Journal of Banking \& Finance, 22, 1283-1316.

Federal Statistic Office (2009). Business Register. Local units with employees liable to pay social insurance contributions in 2007.

Grunert, J., Norden, L., \& Weber, M. (2005). The role of nonfinancial factors in internal credit ratings. Journal of Banking \& Finance, 29, 509-531. 
Hertzberg, A., Liberti, J., \& Paravasini, D. (2010). Information and incentives inside the firm: Evidence from loan officer rotation. Journal of Finance, 65, 795-828.

Heyman, D., Deloof, M., \& Ooghe, H. (2008). The financial structure of privately held Belgian firms. Small Business Economics, 30, 301-313.

Kallberg, J., \& Udell, G. (2003). The value of private sector business credit information sharing: The US case. Journal of Banking and Finance, 27, 449-469.

Kirschenmann, K., \& Norden, L. (2008). The relation between borrower risk and loan maturity in small business lending. Working Paper, University of Mannheim, May 2008.

Liberti, J., \& Mian, A. (2009). Estimating the effect of hierarchies on information use. Review of Financial Studies, 22, 4057-4090.

Mach, T., \& Wolken, J. (2006). Financial services used by small businesses: Evidence from the 2003 survey of small business finances. Federal Reserve Bulletin, 2006, A167-A195.

Machauer, A., \& Weber, M. (1998). Bank behavior based on internal credit ratings of borrowers. Journal of Banking \& Finance, 22, 1355-1383.

National Association of Credit Management. (1965). Credit management handbook (2nd ed., pp. 157-187). Homewood: Irwin.

Norden, L., \& Weber, M. (2010). Credit line usage, checking account activity, and default risk of bank borrowers. Forthcoming, Review of Financial Studies.

Park, Y. (2008). Parsimonious lenders: Bank concentration and Credit Availability to Small Businesses. Working Paper, April 2008.
Petersen, M. (2004). Information: Hard and soft. Working Paper, July 2004.

Petersen, M., \& Rajan, R. (1994). The benefits of lending relationships: Evidence from small business data. Journal of Finance, 49, 3-37.

Petersen, M., \& Rajan, R. (2002). Does distance still matter? The information revolution in small business lending. Journal of Finance, 57, 2533-2570.

Rudolph, K. (2006). Bargaining power effects in financial contracting. Dissertation, Berlin, Springer.

Santos, J., \& Winton, A. (2009). Bank capital, borrower power, and loan rates. Working Paper, February 2009.

Scott, J. (2004). Small business and the value of community financial institutions. Journal of Financial Services Research, 25, 207-230.

Standard \& Poor's. (2006). A guide to the loan market, 2006.

Stein, J. (2002). Information production and capital allocation: Decentralized vs. hierarchical firms. Journal of Finance, 57, 1891-1921.

Uchida, H. (2006). Empirical determinants of bargaining power. Working Paper, Wakayama University, May 2006.

Udell, G. (1989). Loan quality, commercial loan review and loan officer contracting. Journal of Banking \& Finance, 13, 367-382.

Wu, S., \& Wu, A. (2007). Information asymmetry, bargaining power and customer profitability: An empirical investigation on bank-client relationship. Working Paper, University of Illinois at Urbana-Champaign. November 2007. 